\title{
Effect of destoned olive cake on the aromatic profile of cows' milk and dairy products: comparison of two techniques for the headspace aroma profile analysis
}

\author{
Anna Rocchina Caputo, Giuseppe Morone, Maria Antonietta Di Napoli, Domenico Rufrano, \\ Emilio Sabia, Francesco Paladino, Lucia Sepe, Salvatore Claps \\ Consiglio per la ricerca in agricoltura e l'analisi dell'economia agraria, Unità di Ricerca per \\ la Zootecnia Estensiva, Muro Lucano (PZ), Italy
}

\begin{abstract}
The aim of this study, carried out within the NOVOROD project (PSR Campania 2007-2013 Misura $124 \mathrm{HC}$ ), was to evaluate the aromatic profile of milk and dairy products of dairy cows supplemented with destoned olive cake (DOC). Two techniques for the headspace aroma profile analysis: the thermal desorption by gas chromatography with a mass selective (GC/MS) detector and the electronic nose were compared. The trial was performed into a dairy cow farm. Ten dairy cows were allotted into two homogenous groups: control and experimental. Animals received the same diet, while in the experimental group the concentrate supplementation (15\% dry matter) was replaced with DOC. After two weeks of adaptation, animals were fed with the experimental diet for other 15 days. During the experimental period, the milk was collected and cumulatively processed in Caciotta cheese (a soft cheese, 25 days ripened) and in Semicotto cheese (hard cheese, 3 months ripened) for 13 times for each group. Milk and cheese volatile organic compounds (VOCs) were extracted and concentrated with dynamic headspace method and determined by GC/MS. Statistical analysis of data, expressed in arbitrary units (a.u.=peak area $\times 10^{-6}$ ) and allotted in compound classes, was carried out by ANOVA. All data collected of VOCs were processed with
\end{abstract}

Correspondence: Anna Rocchina Caputo, via Appia, Bella Scalo, 85054 Muro Lucano (PZ), Italy.

Tel: +39.0976 .72915 .

E-mail: annarocchina.caputo@entecra.it

Key words: destoned olive cake, headspace aroma profile, milk, dairy products, cows.

Conference presentation: Meeting on Environmental Sustainability and Food Security, Potenza, Italy, 2014.

Received for publication: 3 July 2014.

Revision received: 12 January 2015.

Accepted for publication: 17 January 2015.

(C) Copyright A.R. Caputo et al., 2015

Licensee PAGEPress, Italy

Italian Journal of Agronomy 2015; 10:609

doi:10.4081/ija.2015.609

This article is distributed under the terms of the Creative Commons Attribution Noncommercial License (by-nc 3.0) which permits any noncommercial use, distribution, and reproduction in any medium, provided the original author(s) and source are credited. principal component analysis (PCA). Milk and cheese samples were comparatively analysed with the electronic nose, fitted with a tenmetal oxide sensors electronic device. PCA has been used for the evaluation of the pattern data. Our results show that the use of DOC, as an unconventional feed for livestock, has no effect on the aromatic profile of both milk and dairy products. In fact, no significant differences were found in both milk and dairy products between the two groups using the GC/MS method. Also the discriminating analysis carried out by electronic nose did not show significant differences between the two groups. The two compared techniques seem to lead to the same result.

\section{Introduction}

The use of agro-industrial by-products has taken on considerable importance for animal feeding as a strategy to contribute both to solving the problem of the disposal of waste material and to reducing production costs for livestock feeding (Vasta et al., 2008).

In the Mediterranean area, the olive and olive oil industries have always played an important social and economic role (Molina-Alcaide and Nefzaoui, 1996). This industry produces substantial amounts of by-products and one of the most important is the olive cake (OC), representing approximately $50 \%$ of the conversion process (Servili $e t$ al., 2011). OC use for animal feeding is limited because of the seasonal availability and the low nutritive value, 0.32-0.49 UFL (Nefzaoui, 1991; Aguilera et al., 1992) due to the high lignin content and the high percentage of crude fibre (27-41\%). However, in the sustainable agriculture the $\mathrm{OC}$ use in animal feeding can be useful mainly to reduce the environmental impact of this by-product, provided that the $\mathrm{OC}$ diet integration does not adversely affect the productive performances and the sensory, physico-chemical and aromatic properties of milk, cheese and meat.

The potential use of $\mathrm{OC}$ as a replacer of part of concentrate in diets for domestic animals has been explored. Different studies have been conducted on small ruminants as they are able to utilise the best types of feeding which are characterised by poor nutritive value (Lanzani et al., 1993).

Molina-Alcaide and Yáñez Ruiz (2008) pointed out the effect of OC in small ruminant diets on feed digestibility, milk yield, milk fat content, milk fatty acid quality, also responsible of an increase of milk protein in ewes.

The oxidative stability of lipids in lamb meat is increased by inclusion of destoned OC (DOC) in concentrate-based diets of lambs, specifically when DOC is used in combination with linseed (Luciano et al., 2013). Tufarelli et al. (2013) reported a significant effect of diet with different levels of partly destoned exhausted $\mathrm{OC}$ on growth 
performance and carcass traits of Gentile di Puglia breed lambs. OC administration for feeding ewes played positive effects on milk yield, whereas no effects on chemical composition and clotting properties were shown (Chiofalo et al., 2004). Moreover, OC administration in diet is responsible of an improvement of the dietetic-nutritional characteristics as shown by the increase of the unsaturated/saturated fatty acid ratio and by the decrease of the atherogenic and thrombogenic indices (Chiofalo et al., 2004).

Studies are currently in progress on the use of $\mathrm{OC}$ in diets for cattle. Use of dried $\mathrm{OC}$ in the diet of dairy buffaloes resulted in a high milk content of C18:0 and of C18:3n6 and in high amounts of secoiridoids, main phenolic compounds of olive (Terramoccia et al., 2013).

The fatty acid profile of Caciotta cheese was significantly influenced by nutritional integration of DOC for: saturated, monoinsatured, conjugated linoleic acid, $n-3 / n-6$ content and nutritional indexes (Claps et al., 2012).

No study was found on the effect of DOC on the aromatic profile of milk and dairy products.

The aim of this study was to evaluate the aromatic profile of milk and dairy products of dairy cows supplemented with DOC and to compare the results with two techniques for the headspace volatile compounds analysis: thermal desorption by gas chromatography with a mass selective (GC/MS) detector and electronic nose.

\section{Materials and methods}

\section{Production and composition of destoned olive cake}

DOC was obtained by mechanical extraction of virgin olive oil performed using a Pieralisi Leopard 4 two-phases decanter. DOC has been transported and stored at room temperature, in suitable local of the farm. DOC composition is reported in Table 1.

\section{Animals and diets}

The experiment was performed into a farm of dairy cow in the South Italy area between the months of December and January. Ten dairy Friesan cows were divided into two groups (control and experimental), homogenous for weight (550 kg), distance from calving (60$70 \mathrm{~d})$ and milk production $(28 \mathrm{~kg} / \mathrm{d})$. Animal received the same diet reported in Table 2 and the feed was given as a mixed ration once a day. In the experimental group, the concentrate supplementation was replaced with DOC in a percentage of $15 \%$ dry matter. After 2 weeks of adaptation, animals were fed with the experimental diet for other $15 \mathrm{~d}$.

\section{Milk and cheese samples collection}

Milk was collected and cumulatively processed in Caciotta cheese (a soft cheese, $25 \mathrm{~d}$ ripened) and in Semicotto cheese (hard cheese, 3 months ripened) for 13 times. Samples of milk and cheese were collected and stored at $20^{\circ} \mathrm{C}$ until GC/MS and electronic nose analysis.

\section{Dynamic headspace-gas chromatography with a mass selective detector analysis}

The volatile organic compounds (VOCs) were determined by dynamic headspace (DHS) analysis (Ciccioli et al., 2004) using capillary GC/MS. Fifty $\mathrm{mL}$ of milk sample and $5 \mathrm{~g}$ of cheese were transferred into a $100 \mathrm{~mL}$ and into a $15 \mathrm{~mL}$ glass container, respectively. Subsequently, samples were purged with $50 \mathrm{~mL} / \mathrm{min}$ pure helium gas at $40^{\circ} \mathrm{C}$ in a water bath for $1 \mathrm{~h}$ to isolate headspace volatiles. VOCs were trapped in a glass tube packed with Tenax TA, 60/80 mesh
(Supelco, Bella Fonte, PA, USA), and Carbopack B, 60/80 mesh (Supelco) in a ratio of $2: 1$, respectively. The trapped compounds were thermally desorbed at $250^{\circ} \mathrm{C}$ during 15 min into the Gerstel TDS3 (Gerstel GmbH \& Co. KG, Mellinghofen, Germany), Thermal Desorption System, and cryofocused at $-70^{\circ} \mathrm{C}$ before being injected by heating at $250^{\circ} \mathrm{C}$ in the PTV inlet of CIS4 injector (Agilent Technologies Inc., Wilmington, DE, USA). VOCs were separated on Agilent HP-5MS fused silica capillary column (30 $\mathrm{m} \times 0.25 \mathrm{~mm}$ i.d., $0.25 \mu \mathrm{m}$ film thickness) in Agilent GC 7890A at the following condition: helium flow rate $1 \mathrm{~mL} / \mathrm{min}$, interface open splitless, oven programme: $35^{\circ} \mathrm{C}$ for $5 \mathrm{~min}$, then $5^{\circ} \mathrm{C} / \mathrm{min}$ to $150^{\circ} \mathrm{C}$ for $5 \mathrm{~min}$ and $30^{\circ} \mathrm{C} / \mathrm{min}$ to $270^{\circ} \mathrm{C}$ for $3 \mathrm{~min}$. $\mathrm{GC}$ column was connected to the ion source $\left(230^{\circ} \mathrm{C}\right)$ of a Agilent MSD 5975C quadrupole mass spectrometer (interface line $280^{\circ} \mathrm{C}$ ), operating in the scan mode (40-450 amu). Ionization was done by electronic impact at $70 \mathrm{eV}$; calibration was done by autotuning. The compounds were identified by comparing their mass spectra with those in the Wiley725 Mass Spectral Database and their retention time. Data were expressed as arbitrary unit (a.u.=peak area $\times 10^{-6}$ ).

\section{Electronic nose}

Electronic nose used for this study was a Portable Electronic Nose PEN3 (AIRESENSE Analytics GmbH, Schwerin, Germany) with an array of 10 different metal oxide sensors positioned into a small chamber $(\mathrm{V}=1.8 \mathrm{~mL})$. Detection limit of the hot sensors was in the range of $1 \mathrm{ppm}$. Sensors with good selectivity for sulphur organic compounds, methane, hydrogen, alcohol and hydrocarbons were used. The serial number, main applications and references of the 10 sensors are listed in Table 3 and their sensitive gases were applied according to the manufacture's product manual.

To perform the assay, $1 \mathrm{~g}$ of cheese sample and $15 \mathrm{~mL}$ of milk sample were placed in a $50 \mathrm{~mL}$ vial. Measurements were conducted at a constant temperature $\left(20^{\circ} \mathrm{C}\right.$ for cheese samples and $30^{\circ} \mathrm{C}$ for milk

Table 1. Destoned olive cake composition (\% dry matter).

\begin{tabular}{lc} 
Composition & $\%$ \\
Moisture & 66.18 \\
Crude protein & 6.33 \\
\hline Crude fibre & 21.20 \\
Ether extract & 10.51 \\
\hline Ashes & 7.10 \\
NDF & 54.92 \\
\hline ADF & 42.07 \\
ADL & 22.00 \\
\hline
\end{tabular}

NDF, neutral detergent fibre; ADF, acid detergent fibre; ADL, acid detergent lignin.

Table 2. Formulation of the basic diet ( $\%$ as fed).

\begin{tabular}{lc} 
Composition & $\%$ \\
Silage maize & 52 \\
Hay & 13 \\
\hline Maize flour & 14 \\
Concentrate & 20 \\
\hline Bicarbonate & 1 \\
\hline
\end{tabular}


samples). The sample run lasted $60 \mathrm{~s}$ and was followed by $300 \mathrm{~s}$ flushing time. Each measurement was carried out in triplicate. The set of signals of all sensors during measurement of a sample formed a pattern file. Patterns of multiple measurements dealing with the same problem were stored in a pattern file and acted as a training set. The pattern data were checked and analysed using WinMuster Version 1.6.2.2.

\section{Statistical analysis}

The data obtained with GC/MS were grouped according to their chemical nature in aldehyde, ketone, hydrocarbon, ester, alcohol and terpene classes. Compound class data were submitted to one-way analysis of variance using Systat Statistical Package (Systat 13, 2009) with the diet (control $v s$ experimental diet) as treatment effect. Differences were considered significant at $\mathrm{P} \leq 0.05$. All data collected of VOCs were processed with principal component analysis (PCA) using the previous version (2.16) of the software. PCA for electronic nose pattern data were performed by WinMuster Version 1.6.2.2 software to discriminate between the different samples.

\section{Results}

The VOCs, identified either in milk and cheese, divided in aldehyde, ketone, hydrocarbon, ester, alcohol and terpene classes and expressed in a.u., are shown in Table 4. No significant differences are found between compound classes of control and experimental group, both in milk and in cheese. PCA of milk data (Figure 1A) explained 98.59\% of the total variance, $81.19 \%$ by first principal component (PC1) and $17.40 \%$ by second principal component (PC2), and did not discriminate between the two groups, which overlapped. As regard VOCs of Caciotta cheese and Semicotto cheese (Figures 2A and 3A, respectively), PCA explained $93.96 \%$ ( $87.37 \%$ by $\mathrm{PC} 1$ and $6.59 \%$ by PC2) and $89.29 \%$ ( $76.31 \%$ by PC1 and $12.98 \%$ by PC2) of the total variance, respectively. No differences were found both in Caciotta cheese and in Semicotto cheese.

Also the results of the electronic nose have shown that the use of DOC has not affected footprint olfactory both the milk and cheese. PCA of electronic nose pattern data are presented in Figure 1B (95.37\% of variance: $88.41 \%$ by PC1 and $6.96 \%$ by PC2) for milk, in Figure 2B for Caciotta cheese (98.37\% of variance: $89.86 \%$ by $\mathrm{PC} 1$ and $8.51 \%$ by PC2) and in Figure 3B for Semicotto cheese $(89.57 \%$ of variance: $70.31 \%$ by $\mathrm{PC} 1$ and $19.26 \%$ by PC2).

\section{Discussion}

Our results, obtained both with GC/MS analysis and with electronic nose, show no effect of DOC on the aromatic profile of cows' milk and dairy products. Moreover, these results support the possibility of DOC use for cow feeding, also because, according to literature (MolinaAlcaide et al., 2008; Tufarelli et al., 2013; Chiofalo et al., 2004), D0C has not negative effects on productive performances and on the physico-chemical properties of milk, cheese and meat. Furthermore

Table 3. Sensors description and their references in electronic nose.

\begin{tabular}{lll} 
Sensor number & General description & Reference \\
S1 & Aromatic compounds & Toluene, $10 \mathrm{ppm}$ \\
S2 & Very sensitive, broad range sensitivity, to nitrogen oxides & $\mathrm{NO}_{2}, 1 \mathrm{ppm}$ \\
\hline S3 & Ammonia, used as sensor for aromatic compounds & Benzene, $10 \mathrm{ppm}$ \\
S4 & Mainly hydrogen, selectively (breath gases) & $\mathrm{H}_{2}, 100 \mathrm{ppb}$ \\
\hline S5 & Alkenes, aromatic compounds, less polar compounds & Propane, $1 \mathrm{ppm}$ \\
S6 & Sensitive to methane broad range & $\mathrm{CH}_{3}, 100 \mathrm{ppm}$ \\
\hline S7 & Reacts on sulphur compounds & $\mathrm{H}_{2} \mathrm{~S}, 1 \mathrm{ppm}$ \\
S8 & Detects alcohols, partially aromatic compounds & $\mathrm{CO}_{1}, 100 \mathrm{ppm}$ \\
\hline S9 & Aromatics compounds, sulphur organic compounds & $\mathrm{H}_{2} \mathrm{~S}, 1 \mathrm{ppm}$ \\
S10 & Reacts on high concentrations & $\mathrm{CH}_{3}, 100 \mathrm{ppm}$ \\
\hline
\end{tabular}

Table 4. Effect of destoned olive cake on the aromatic compound classes.

\begin{tabular}{|c|c|c|c|c|c|c|c|c|c|c|c|c|}
\hline \multirow[t]{2}{*}{ Compounds classes* } & \multicolumn{4}{|c|}{ Milk } & \multicolumn{4}{|c|}{ Caciotta cheese } & \multicolumn{4}{|c|}{ Semicotto cheese } \\
\hline & $\begin{array}{c}\text { Control } \\
\text { group }\end{array}$ & $\begin{array}{l}\text { DOC } \\
\text { group }\end{array}$ & SE & $\mathbf{P}$ & $\begin{array}{c}\text { Control } \\
\text { group }\end{array}$ & $\begin{array}{l}\text { DOC } \\
\text { group }\end{array}$ & SE & $\mathbf{P}$ & $\begin{array}{c}\text { Control } \\
\text { group }\end{array}$ & $\begin{array}{l}\text { DOC } \\
\text { group }\end{array}$ & SE & $\mathbf{P}$ \\
\hline Aldehydes & 206.41 & 244.34 & 32.09 & ns & 135.46 & 121.06 & 13.81 & ns & 116.03 & 120.57 & 13.75 & ns \\
\hline Ketones & 21.16 & 26.47 & 6.73 & ns & 5.29 & 5.42 & 1.32 & ns & 8.66 & 14.05 & 3.60 & ns \\
\hline Hydrocarbons & 29.34 & 33.31 & 2.93 & ns & 36.30 & 33.78 & 3.00 & ns & 31.34 & 34.33 & 2.92 & ns \\
\hline Esters & 29.34 & 42.98 & 8.53 & ns & 11.63 & 10.11 & 1.39 & ns & 14.42 & 12.96 & 2.15 & ns \\
\hline Alcohols & 86.30 & 165,00 & 52.30 & ns & 39.05 & 30.04 & 4.38 & ns & 29.89 & 26.55 & 3.84 & ns \\
\hline Terpenes & 93.46 & 102.55 & 6.09 & ns & 89.39 & 78.88 & 6.72 & ns & 73.71 & 68.27 & 5.25 & ns \\
\hline
\end{tabular}

*Arbitrary units (a.u.=peak area $\times 10^{-6}$ ). DOC, destoned olive cake; SE, standard error; ns, not significant. 
Chiofalo et al. (2004) have not observed sensory peroxidative phenomena during cheese manufacturing and seasoning.

The second objective of this study was the comparison between the two different techniques used.

The headspace technique, in particular the DHS, is a very popular method for analysing volatile compounds in food (Canac-Arteaga, 2001). Many papers have investigated changes in volatile flavour compounds in milk and dairy products due to different feeding (Fedele $e t$ $a l ., 2005)$, in fermented dairy products due to different starter cultures (Imhof and Bosset, 1994) and during cheese ripening (Thierry et al.,
1999). However, this method is time consuming and costly, particularly when used for routine analysis purposes and it does not allow to establish whether such compounds are odour-active or not.

In recent years, electronic nose has been gaining attention as useful tool, especially for quality control in food and beverage industries. It is ideally suited for rapid screening capacity, but although it does not discriminate singular VOCs.

Electronic nose could discriminate different organoleptic properties (qualities, origins, defects and concentration of pollutant) of different samples. Many studies have investigated the use of electronic

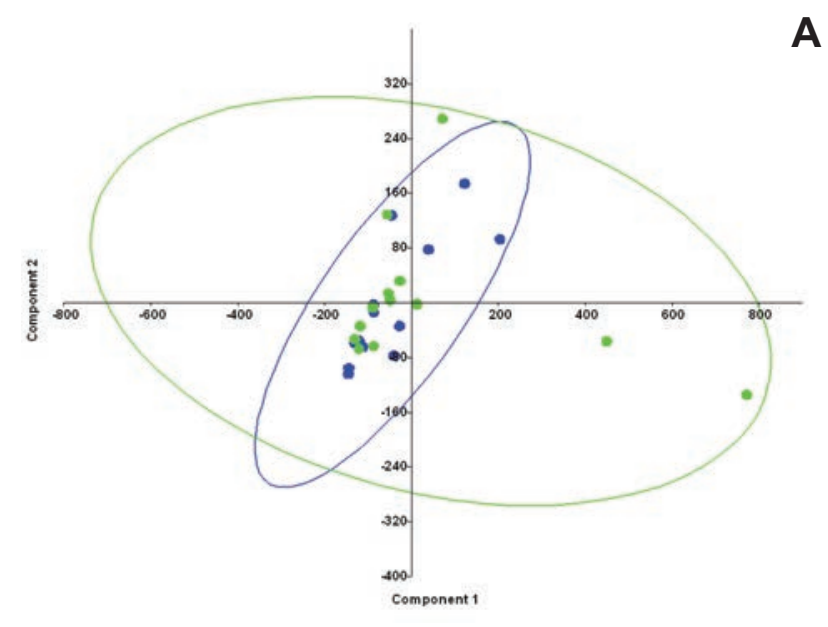

A

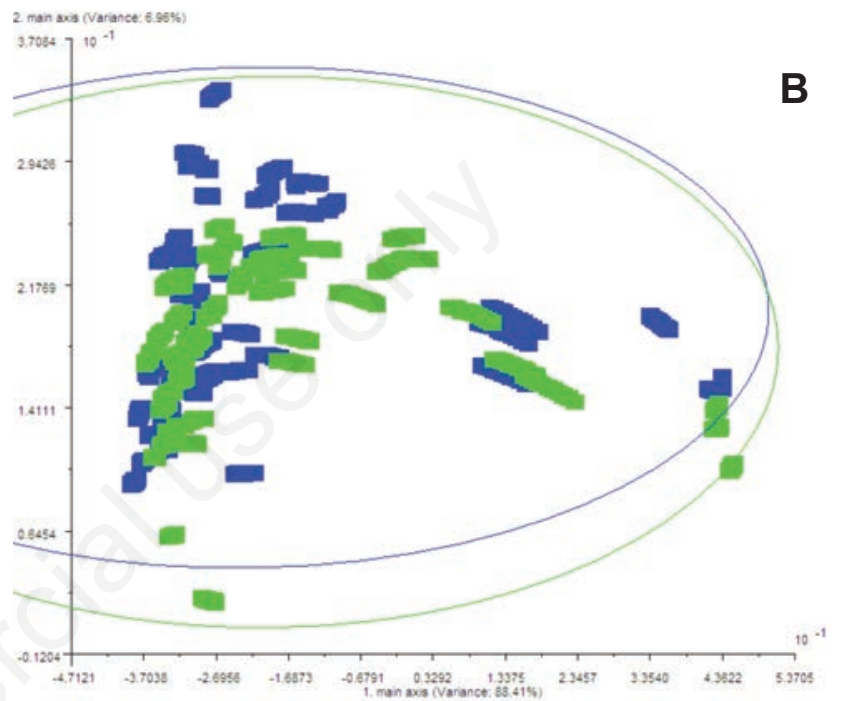

Figure 1. Principal component analysis of milk data: control group (blue area) vs experimental group (green area): A) dynamic headspace-gas chromatography with a mass selective detector; B) electronic nose.

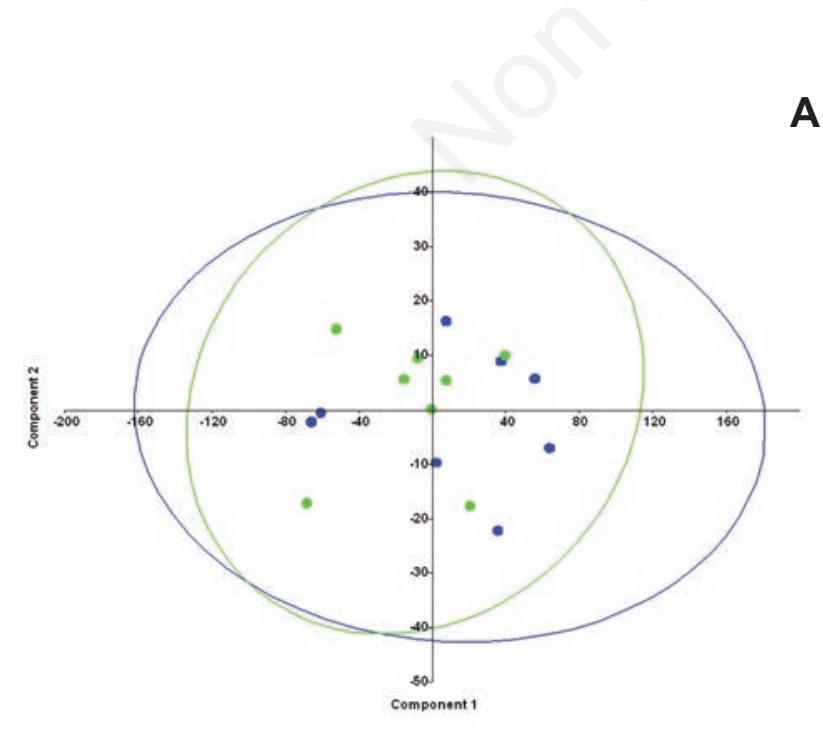

A

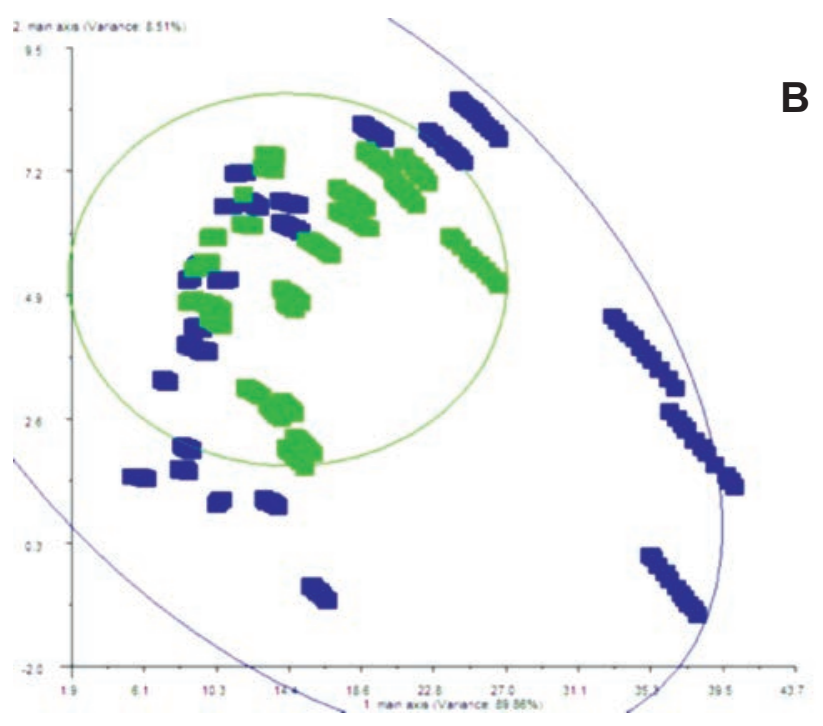

Figure 2. Principal component analysis of Caciotta cheese data: control group (blue area) vs experimental group (green area): A) dynamic headspace-gas chromatography with a mass selective detector; B) electronic nose. 


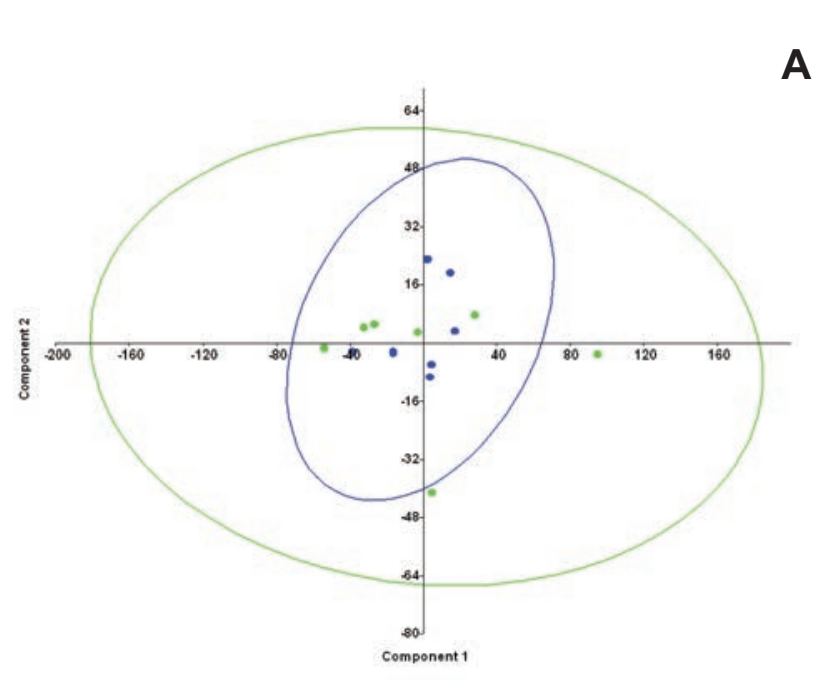

A

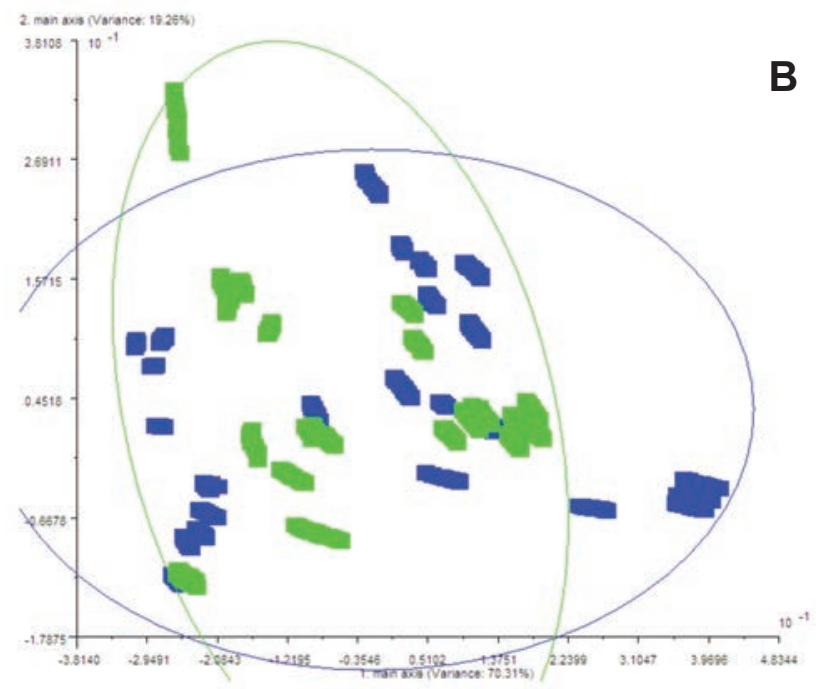

Figure 3. Principal component analysis of Semicotto cheese data: control group (blue area) vs experimental group (green area): A) dynamic headspace-gas chromatography with a mass selective detector; B) electronic nose.

nose for aroma compound analysis of dairy products (Ampuero and Bosset, 2003), for the determination of the geographic origin of cheese (Pillonel et al., 2003), for the shelf-life determination of milk and for monitoring the cheese ripening process.

Comparative studies on the use of different techniques for the headspace aroma profile analysis were carried out on different food products like fish (Sun et al., 2013), while few comparative studies on milk and cheese were carried out (Pillonel et al., 2003). The use of the two techniques of investigation and the combined approach allow for a more complete understanding of the flavour profile.

\section{Conclusions}

The use of DOC, as an unconventional feed for livestock, has no effect on the aromatic profile of both milk and dairy products.

The results of two compared techniques seem to lead to the same conclusion. Here we have shown that data collected by electronic nose support its use as viable method for rapid detection of aromatic profile of milk and dairy products. The combination of the DHS$\mathrm{GC} / \mathrm{MS}$ and the electronic nose provides a great deal of information and a more complete picture of milk and dairy product complex flavour.

\section{References}

Aguilera JF, Garcia MA, Molina E, 1992. The performance of ewes offered concentrates containing olive by-products in late pregnancy and lactation. Anim. Prod. 55:219-26.

Ampuero S, Bosset J0, 2003. The electronic nose applied to dairy products: A review. Sensor Actuators B 94:1-12.

Canac-Arteaga D, 2001. Contribution à l'amélioration de l'analyse de la fraction volatile de produits riches en eau par espace de tête dinamique couplé à la chromatographie en phase gazeuse et spectrométrie de masse. Ph. D. Thesis, no. 346, Université Blaise Pascal, Clermont-Ferrand, France.
Chiofalo B, Liotta L, Zumbo A, Chiofalo V, 2004. Administration of olive cake for ewe feeding: effect on milk yield and composition. Small Rumin. Res. 55:169-76.

Ciccioli P, Brancaleoni E, Frattoni M, Fedele V, Claps S, Signorelli F, 2004. Quantitative determination of volatile organic compounds (VOC) in milk by multiple dynamic headspace extraction and GC/MS. Ann. Chim. 94:669-78.

Claps S, Sepe L, Fedele V, Caputo AR, Di Napoli MA, Paladino F, Sabia E, Rufrano D, 2012. L'uso dei sottoprodotti industriali per il miglioramento della qualità nutrizionale dei formaggi. Page 47 in Convegno Altri Formaggi, 29 November - 1 Dicember, Avellino, Italy.

Fedele V, Rubino R, Claps S, Sepe L, Morone G, 2005. Seasonal evolution of volatile compounds content and aromatic profile in milk and cheese from grazing goat. Small Rumin. Res. 59:273-9.

Imhof R, Bosset J0, 1994. Relationships between micro-organism and formation of aroma compounds in fermented dairy products. $\mathrm{Z}$. Lebensm. Unters. Forsch. 198:267-76.

Lanzani A, Bondioli P, Folegatti L, Fedeli E, Bontempo V, Chiofalo V, Panichini G, Dell'Orto V, 1993. Impiego di sanse di olive integrate nell'alimentazione della pecora da latte: effetti sulle produzioni quali-quantitative di latte (integrated olive husks applied to the sheep feeding: influences on the quali-quantitative production of milk). Riv. Ital. Sost. Grasse. 70:375-83.

Luciano G, Pauselli M, Servili M, Mourvaki E, Serra A, Monahan FJ, Lanza M, Priolo A, Zinnai A, Mele M, 2013. Dietary olive cake reduces the oxidation of lipids, including cholesterol, in lamb meat enriched in polyunsaturated fatty acids. Meat Sci. 93:703-14.

Molina-Alcaide E, Nefzaoui A, 1996. Recycling of olive oil by products: possibilities of utilization in animal nutrition. Int. Biodeterior. Biodegrad. 38:227-35.

Molina-Alcaide E, Yáñez Ruiz DR, 2008. Potential use of olive by-products in ruminant feeding: A review. Anim. Feed Sci. Technol. 147:247-64.

Nefzaoui A, 1991. Valorisation des sous-produits de l'olivier. Option Mediter. 16:101-8.

Pillonel L, Ampuero S, Tabacchi R, Bosset J0, 2003. Analitycal mathods for the determination of the geographic origin of Emmental cheese: Volatile compounds by GC/MS-FID and electronic nose. 
Eur. Food Res. Tech. 216:179-83.

Servili M, Esposto S, Urbani S, Taticchi A, Petruccioli M, 2011. Utilizzazione dei reflui oleari. In: Ricci A (a cura di), Oleum. Manuale dell'olio da olive. Ed. Agricole, Milano, Italy, p 174.

Sun J, Wang QJ, Huang J, Hou YD, Chen YF, Su XR, 2013. Influence of heating temperature on the development of volatile compounds in bigeye tuna meat (Thunnus obesus) as assessed by E-nose and SPME-GC/MS. Int. Food Res. J. 20:3077-83.

Terramoccia S, Bartocci S, Taticchi A, Di Giovanni S, Pauselli M, Mourvaki E, Urbani S, Servili M, 2013. Use of dried stoned olive pomace in the feeding of lactating buffaloes: effect on the quantity and quality of the milk produced. Asian Australas. J. Anim. Sci. 26:971-80.

Thierry A, Maillard MB, Le Quéré JL, 1999. Dynamic headspace analysis of Emmental aqueous phase as a method to quantify changes in volatile flavour compounds during ripening. Int. Dairy J. 9:453:63.

Tufarelli V, Introna M, Cazzato E, Mazzei D, Laudadio V, 2013. Suitable of partly destoned exhauste olive cake as by-products feed ingredient for lamb production. J. Anim. Sci. 91:872-7.

Vasta V, Nudda A, Cannas A, Lanza M, Priolo A, 2008. Alternative feed resources and their effects on the quality of meat and milk from small ruminants. Anim. Feed Sci. Technol. 147:223-46. 